\title{
SOAL MATEMATIKA MODEL PISA: ALTERNATIF MATERI PROGRAM PENGAYAAN
}

\author{
Andi Harpeni Dewantara \\ penidewantara@gmail.com \\ Program Studi Pendidikan Guru Madrasah Ibtidaiyah \\ Institut Agama Islam Negeri (IAIN) Bone
}

\begin{abstract}
In a learning process, each students' has different level of capability in mastering the teaching materials. For those who belong to the fast learner group and are able to achieve mastery learning earlier, ideally they need an additional learning activities to develop their skills more optimally. One of such learning activities is commonly known as the enrichment programs. Then, one of the learning challenges that can be applied in this enrichment program is proposing problem solving tasks to foster students' high order thinking skills. Based on the characteristics, it is revealed that PISA problems or PISA-like tasks has characteristics that are very in accordance with the characteristics of the rocemmenced enrichment problems. So that is why PISA problems or PISAlike tasks could be highly regarded as the enrichment tasks for students who have achieved early learning completeness. PISA mathematics problems or PISA-like mathematics tasks is expected to be able to optimize students 'mathematical literacy skills through activation of basic mathematical abilities, which in turn can help the success of enrichment programs in developing students' skills more optimally.
\end{abstract}

Keywords: enrichment materials, PISA-like tasks, mathematical literacy

\section{PENDAHULUAN}

Dalam sebuah pembelajaran, tidak dapat dipungkiri bahwa kemampuan dan tingkat daya serap masing-masing siswa berbeda-beda. Sebagai konsekuensi, kecepatan penguasaan terhadap kompetensi dasar yang telah ditetapkan pada suatu materi ajar tidaklah sama antara 
siswa yang satu dengan yang lainnya. Bagi mereka yang mampu mencapai ketuntasan belajar lebih awal, idealnya diperlukan aktivitas belajar tambahan di luar dari pembelajaran biasa guna mengembangkan kecakapan siswa secara lebih optimal. Salah satu alternatif aktivitas belajar tersebut yakni dengan pemberian program pengayaan. Hal ini sejalan dengan apa yang dikemukakan oleh Wardani (2014:3) bahwa sekolah perlu memberikan perlakuan khusus berupa pemberian program pengayaan kepada siswa yang lebih cepat mencapai penguasaan kompetensi minimal yang telah ditetapkan.

Secara umum, program pengayaan merupakan pemberian aktivitas dan pengalaman belajar yang berbeda dari pembelajaran rutin kepada siswa yang telah melampaui persyaratan minimal yang ditentukan oleh kurikulum, guna memperoleh pengalaman belajar dengan level yang lebih tinggi. Hal ini menunjukkan bahwa pemberian program pengayaan tidak mesti ditujukan kepada seluruh siswa, melainkan bagi siswa-siswa tertentu saja yakni mereka yang telah mencapai ketuntasan belajar lebih awal (Lalley \& Gentile: 2003).

Program pengayaan dapat dilakukan dengan memberikan tantangan belajar pada level yang lebih tinggi kepada peserta didik. Salah satu aktivitas yang dapat diadopsi dalam program pengayaan yakni pemberian soal-soal pemecahan masalah atau permasalah dunia nyata (Renzuli \& Reis, 2005; Depdiknas, 2008; Sanova, 2008). Tantangan belajar ini sejalan dengan program pengayaan tipe II yang dikemukakan oleh Renzulli \& Reis (2005), yaitu berupa pemberian materi dan sederet aktivitas belajar, salah satunya dengan pemberian soalsoal pemecahan masalah, guna mengoptimalkan kemampuan berpikir tingkat tinggi dan kemampuan invastigatis siswa.

Lebih lanjut, Rule, dkk (2012; Sanova, 2017) mengemukakan bahwa soal-soal yang diberikan pada program pengayaan idealnya adalah soal pemecahan masalah dengan level lebih tinggi daripada soal rutin, yang diharapkan mampu mengeksplorasi kemampuan siswa dalam berargumentasi, membandingkan, mengevaluasi, mengambil keputusan serta menarik kesimpulan.

Berdasarkan uraian tersebut, soal-soal pemecahan masalah non rutin atau level tinggi dipandang sangat sesuai untuk diberikan kepada siswa dalam program pengayaan. Dalam pemberian soal-soal level tinggi tersebut, guru sebaiknya tidak hanya terpaku pada soal-soal latihan biasa yang ada pada buku teks saja (Gustiningsi, 2016). Diperlukan upaya guru dalam menghadirkan soal-soal yang mampu mengaktivasi kemampuan berpikir tingkat tinggi (high order thinking) siswa. Soal pemecahan masalah non rutin yang dapat digunakan salah satunya adalah soal model PISA. PISA merupakan program internasional tiga tahunan 
yang dikoordinasikan oleh OECD untuk mengevaluasi kemampuan literasi membaca, sains dan matematika siswa-siswa usia 15 tahun di negara pesertanya.

Literasi matematis merupakan satu dari tiga kemampuan yang menjadi fokus penilaian dalam PISA. Fokus dari kemampuan ini adalah siswa dapat merumuskan, menerapkan, dan menginterpretasian matematika ke dalam berbagai konteks yang mencakup penalaran matematis dan menggunakan konsep matematika, prosedur, fakta, dan alat untuk menggambarkan, menjelaskan, dan memprediksi fenomena dalam kehidupan sehari-hari (OECD, 2013).

Soal-soal yang telah diujikan dalam survey internasional PISA atau soal-soal yang dikembangkan serupa dengan soal PISA (soal model PISA) pun dapat menjadi alternatif sebagai bahan materi program pengayaan di kelas.

\section{A. Program Pengayaan}

Program pengayaan merupakan upaya perubahan dan penambahan kurikulum reguler dalam rangka pemenuhan kebutuhan bakat dan kemampuan siswa di bidang kognitif, afektif, kreatif dan psikomotorik (Van Tessel-Baska \& Brown, 2007; Alzhoubi, 2014; Gustiningsi, 2016). Program pengayaan pada umumnya diberikan kepada peserta didik yang dianggap telah melampaui persyaratan minimal yang telah ditentukan oleh kurikulum. Sebab tidak dapat dipungkiri bahwa dalam sebuah pembelajaran, seringkali dijumpai adanya peserta didik yang lebih cepat dalam mencapai standar kompetensi, kompetensi dasar dan penguasaan materi ajar yang telah ditentukan. Dengan kata lain, program pengayaan tidak mesti ditujukan untuk seluruh siswa, melainkan hanya bagi mereka yang telah mencapai ketuntasan belajar lebih awal. Hal ini juga ditegaskan dalam Peraturan Menteri Nomor 58 (2014) bahwa program pengayaan diterapkan bagi peserta didik yang termasuk ke dalam kategori pembelajar cepat.

Program pengayaan dapat didesain dengan memberikan tantangan belajar pada level yang lebih tinggi kepada peserta didik guna mengoptimalkan aktivasi kemampuan kognitif, afektif, dan psikomotorik mereka. Salah satu tantangan belajar yang dapat diterapkan dalam program pengayaan ini yakni pemberian soal-soal pemecahan untuk melatih kemampuan berpikir tingkat tinggi (high order thinking) siswa. Aktivitas belajar tersebut sesuai dengan salah satu tipe program pengayaan yang dikemukakan oleh Renzulli \& Reis (2005), yakni program pengayaan tipe II berupa pemberian materi dan sederet aktivitas belajar guna 
mengoptimalkan kemampuan berpikir tingkat tinggi dan kemampuan invastigatis siswa,salah satunya dengan pemberian soal-soal pemecahan masalah.

\section{B. PISA (Programme for International Student Assesment)}

PISA adalah studi internasional yang diselenggarakan secara berkala yaitu setiap tiga tahun sekali dengan tujuan untuk mengukur prestasi literasi, matematika, dan sains siswa sekolah berusia 15 tahun di negara-negara peserta. Studi ini dikoordinasikan oleh OECD (Organisation for Cooperation and Development) yang berkedudukan di Paris, Perancis (OECD, 2010; 2013a). Fokus dari PISA adalah literasi yang menekankan pada keterampilan dan kompetensi siswa yang diperoleh dari sekolah dan dapat digunakan dalam kehidupan sehari-hari dan dalam berbagai situasi (OECD, 2013a; OECD, 2013b, Stacey, 2011).

Secara umum, PISA dirancang dengan maksud untuk mengumpulkan informasi terkait literasi siswa dalam tiga domain utama, yakni membaca, matematikadan sains. Selain itu, asesmen reguler tiga tahunan ini juga dapat memberi informasi tentang faktor-faktor yang mempengaruhi perkembangan kemampuan dan sikap siswa dan juga bagaimana faktor-faktor tersebut berintegrasi sehingga mempengaruhi perkembangan kebijakan suatu negara (OECD, 2010; Johar, 2012).

PISA diselenggarakan pertama kali pada tahun 2000 dengan menempatkan kemampuan membaca menjadi domain utama yang dinilai. Dalam tiap pelaksanaannya, domain utama dari kajian studi PISA bergantian dari kemampuan membaca, matematika, dan sains. Pada pelaksanaan PISA yang diselenggarakan pada tahun 2012, matematika ditempatkan sebagai domain mayor (OECD, 2013a). Sedangkan dalam studi PISA 2015, matematika akan diujikan sebagai domain minor (OECD, 2013b).

Namun dalam pelaksanaan PISA secara berturut-turut di tahun 2000, 2003, 2006, 2009, dan 2012, prestasi matematika siswa-siswa Indonesia belum menunjukkan hasil yang menggembirakan. Indonesia tetap konsisten menempati urutan 10 terendah di antara negara-negara peserta PISA lainnya (OECD, 2013a). Level pencapaian siswa pada lima kali pelaksanaan PISA pun terbilang rendah. Sebanyak 76,7\% siswa belum mampu mencapai level 2 pada survey PISA 2009 (OECD, 2013a; Stacey, 2011). Hasil studi terbaru PISA 2012 juga menunjukkan hasil serupa, sebagian besar siswa Indonesia $(75,7 \%)$ belum mampu mencapai level 2 dan hanya 0,3\% saja yang mampu mencapai level 5 dan 6 (OECD, 2014). Padahal menurut Stacey (2011), level 2 merepresentasikan level dasar kemampuan 
matematika dalam PISA dimana siswa mulai mendemonstrasikan kemampuan matematika yang penting untuk perkembangan masa depannya.

Dalam melakukan studi ini, setiap negara harus mengikuti prosedur operasi standar yang telah ditetapkan. Bagi Indonesia, manfaat yang dapat diperoleh antara lain adalah untuk mengetahui posisi prestasi siswa Indonesia dibandingkan dengan prestasi literasi siswa di negara lain dan faktor-faktor yang mempengaruhinya. Oleh karena itu, hasil siswa tersebut diharapkan dapat digunakan sebagai masukan dalam perumusan kebijakan untuk peningkatan mutu pendidikan.

\section{Domain PISA untuk Matematika}

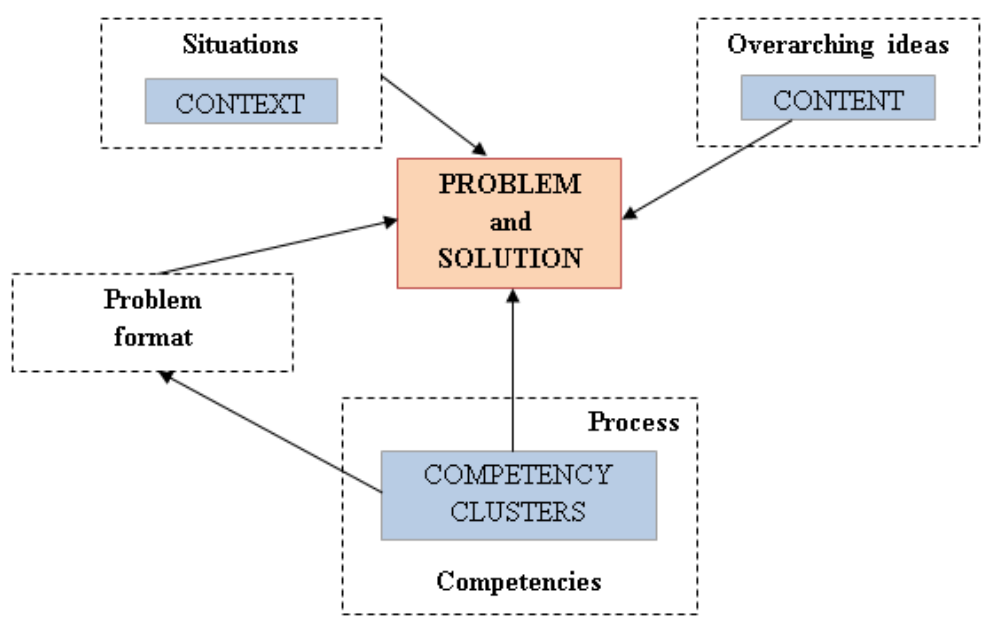

Gambar 1. Domain PISA untuk Matematika

OECD (dalam Johar, 2012) menjelaskan bahwa PISA meliputi tiga komponen mayor dari domain matematika, yakni context (konteks), content (konten), dan competency cluster (kompetensi), sebagaimana tergambar dalam bagan di atas.

\section{Konten dalam PISA}

Masalah yang disajikan dalam PISA erat kaitannya dengan fenomena. Dalam PISA, fenomena tersebut dikenal sebagai over-arching ideas. Terdapat empat kategori overarching ideas atau konten matematika dalam PISA (OECD, 2013a; OECD, 2013b), yaitu:

a. Change and Relationships (Perubahan dan Hubungan)

Perubahan dan hubungan di dunia ini dapat terjadi secara alami maupun sengaja didesain oleh manusia. Sifatnya pun beragam, ada yang bersifat terus menerus, bersiklus, permanen, dan sementara, misalnya perubahan jumlah penduduk di suatu daerah, 
perkembangan organisme, siklus musim, fluktuasi indeks saham, perubahan nilai kurs mata uang, dan sebagainya. Konten perubahan dan hubungan berkaitan dengan pemahaman pada tipe-tipe mendasar dari perubahan yang membutuhkan pemodelan matematika dalam menjelaskan dan memprediksi suatu fenomena yang terjadi. Secara matematis, konten ini berhubungan dengan fungsi dan dan aljabar, termasuk ekspresi aljabar, persamaan dan pertidaksamaan, serta menciptakan, menafsirkan dan menerjemahkan antara representasi simbolis dan grafis dari hubungan-hubungan matematika.

b. Space and Shape (Ruang dan Bentuk)

Ruang dan bentuk merupakan fenomena yang dapat kita jumpai di mana saja yang terbentuk dari dunia visual dan fisik seperti pola, bentuk visual, sifat, posisi dan arah benda, menafsirkan informasi visual, interaksi dinamis dengan bentuk yang nyata. Soal tentang ruang dan bentuk ini menguji kemampuan siswa dalam mengenali bentuk, mencari persamaan dan perbedaan dalam berbagai dimensi dan representasi bentuk, serta mengenali ciri suatu benda dalam hubungannya dengan posisi benda tersebut.

c. Quantity (Bilangan)

Bilangan berkaitan dengan hubungan bilangan dan pola bilangan, antara lain kemampuan untuk memahami ukuran, pengenalan pola bilangan, penggunaan angka untuk mewakili jumlah dan sifat objek nyata, kemampuan merepresentasikan sesuatu dalam angka, dan segala sesuatu yang berhubungan dengan bilangan dalam kehidupan sehari-hari. Aspek penting terkait konten quantity yaitu kemampuan bernalar secara kuantitatif. Komponen penting dalam pemikiran kuantitatif antara lainnumber sense, memahami makna operasi, perhitungan matematika, mental aritmatika, dan estimasi/ perkiraan.

Beberapa domain konten quantity yang paling sering digunakan dalam kehidupan sehari-hari misalnya pengukuran jarak, panjang, luas, volume, tinggi, massa, kecepatan, tekanan, dan nilai tukar mata uang. Memahami makna operasi meliputi kemampuan pengoperasian termasuk perbandingan, rasio, dan persentase.Memiliki pemahaman yang baik tentang bilangan memungkinkan siswa dalam memodelkan sesuatu, menguji perubahan dan hubungan, mendeskripsikan dan memanipulasi bentuk dan ruang, menyusun data, dan menghitung ketidakpastian. 


\section{d. Uncertainty and Data (Ketidakpastian dan Data)}

Konten uncertainty dan data ini berhubungan erat dengan domain statistik dan peluang. Dalam kehidupan sehari-hari, konten ketidakpastian dan data sering dijumpai dalam kehidupan sehari-hari, seperti data tentang pertumbuhan penduduk di suatu daerah, tingkat kemiskinan di suatu negara, fluktuasi indeks saham, hasil pemilu, hasil jajak pendapat, perkiraan cuaca, hasil survey dan lain sebagainya. Konsep dan aktivitas matematika yang penting pada bagian ini adalah mengumpulkan data, analisis dan menyajikan data, peluang, dan inferensi.

Meskipun dalam PISA matematika terdapat empat macam kategori konten, namun tidak ada pemetaan khusus antara suatu topik matematika tertentu terhadap masingmasing konten tersebut. (OECD, 2013b).

\section{Konteks dalam PISA}

PISA menguji kemampuan siswa dalam menganalisis, bernalar, dan mengkomunikasikan gagasan matematika secara efektif, serta merumuskan dan menafsirkan masalah matematika dalam proses pemecahan masalah di berbagai konteks. Untuk menjadi seorang pemecah masalah (problem solver) yang baik, siswa diharapkan mampu bekerja dalam berbagai konteks. Sehubungan dengan hal ini, dalam framework PISA (OECD, 2013a; OECD, 2013b) disebutkan bahwa konteks matematika dalam PISA dapat dikategorikan menjadi empat, yaitu:

\section{a. Personal (Konteks Pribadi)}

Konteks pribadi berfokus pada permasalahan yang berhubungan langsung dengan aktivitas pribadi siswa, baik kegiatan diri sendiri, kegiatan dengan keluarga, maupun dengan kegiatan dengan teman sebaya.Permasalahan nyata yang termasuk dalam konteks personal diantaranya makanan, kesehatan pribadi, belanja, permainan, olahraga, transportasi pribadi, perjalanan, serta permasalahan yang berkaitan dengan keuangan dan penjadwalan pribadi.

\section{b. Occupational (Konteks Pekerjaan)}

Konteks pekerjaan berfokus pada tempat dan lingkungan kerja. Konteks pekerjaan ini dapat berupa hal-hal seperti mengukur, biaya dan pemesanan bahan bangunan, menghitung gaji, pengendalian mutu, penjadwalan, desain/arsitektur, dan pekerjaan yang berhubungan dengan pengambilan keputusan.

c. Societal (Konteks Umum) 
Konteks umum berhubungan dengan penggunaan pengetahuan matematika dalam kehidupan bermasyarakat baik lokal, nasional, maupun global. Konteks ini dapat berupa masalah sistem pemilihan, angkutan umum, pemerintah, kebijakan publik, demografi, periklanan, statistik nasional, masalah ekonomi, dan lain sebagainya. Walaupun seseorang dilibatkan dalam segala hal secara pribadi, namun konteks sosial difokuskan pada masalah yang ada dalam masyarakat.Oleh karenanya, siswa dapat menyumbangkan pemahaman mereka tentang pengetahuan dan konsep matematikanya untuk mengevaluasi berbagai situasi yang relevan dalam kehidupan di masyarakat.

\section{d. Scientific (Konteks Ilmiah)}

Konteks ilmiah dalam PISA secara khusus berhubungan dengan kegiatan ilmiah yang lebih abstrak dan penguasaan teori secara mendalam yang digunakan dalam melakukan pemecahan matematika. Konteks ilmiah juga berkaitan dengan penerapan matematika di alam, isu-isu dan topik-topik yang berkaitan dengan ilmu pengetahuan dan teknologi, seperti cuaca atau iklim, ekologi, kedokteran, ilmu ruang, genetika, pengukuran, dan dunia matematika itu sendiri. Ketika sebuah soal hanya melibatkan konstruksi matematika saja tanpa berhubungan sama sekali dengan masalah dunia nyata, maka soal ini digolongkan ke dalam konteks ilmiah.

\section{Kemampuan Dasar Matematika menurut PISA}

Kemampuan dasar matematis yang seyogyanya dilibatkan dalam penyelesaian masalah menurut PISA (OECD, 2013b; Turner, 2012) adalah sebagai berikut:

\section{a. Komunikasi (Communication)}

Literasi matematika melibatkan kemampuan untuk mengkomunikasikan masalah. Ketika dihadapkan pada suatu permasalahan, siswa diharapkan merasa tertantang untuk mengenali dan memahami masalah, membaca, memahami simbol, dan menafsirkan pernyataan, pertanyaan, tugas atau objek yang memungkinkan siswa untuk membuat model matematika sebagai suatu langkah penyelesaian masalah tersebut. Komunikasi yang dimaksud adalah bagaimana menafsirkan informasi-informasi yang relevan. Aktivasi dari kemampuan komunikasi akan semakin meningkat seiring dengan semakin kompleksnya materi yang ditafsirkan dalam memahami sebuah masalah.

b. Matematisasi (Mathematizing)

Literasi matematika melibatkan kemampuan untuk mengubah (transform) permasalahan dari dunia nyata ke dalam bentuk matematika, termasuk di dalamnya membuat struktur, 
konsep, membuat asumsi-asumsi, dan/atau merumuskan sebuah model, menafsirkan/mengevaluasi hasil matematika atau model matematika yang berkaitan dengan masalah yang diberikan. Selanjutnya, Turner (2012) mengemukakan bahwa aktivasi dari kemampuan matematisasi semakin bertambah seiring dengan bertambahnya tingkat kreativitas, wawasan yang mendalam,dan pengetahuan yang dibutuhkan untuk menerjemahkan konteks ke dalam struktur matematika dari masalah yang dipecahkan.

c. Representasi (Representation)

Kemampuan untuk menyajikan kembali (representasi) suatu permasalahan atau suatu objek matematika dapat diartikan sebagai kegiatan memlilih, menafsirkan, menerjemahkan, dan menggunakan berbagai representasi untuk memahami masalah, atau untuk mempresentasikan hasil kerja seseorang. Bentuk-bentuk representasi yang dimaksud meliputi grafik, tabel, diagram, gambar, persamaan, rumus, dan benda-benda konkrit (OECD, 2013b).

d. Penalaran dan Argumentasi (Reasoning and Argument)

Kemampuan ini melibatkan proses berpikir logis yang mengeksplorasi dan menghubungkan elemen-elemen masalah sehingga dapat membuat kesimpulan dari elemen-elemen tersebut, memeriksa pembenaran yang diberikan, atau memberikan pembenaran laporan atau solusi untuk masalah (OECD, 2013b). Turner (2012) mengungkapkan bahwa banyaknya rantai argumentasi dan penalaran berikut dengan kompleksitasnya berperan penting sebagai kontributor terhadap bertambahnya level dari kompetensi ini.

e. Merancang Strategi untuk Memecahkan Masalah (Devising Strategies for Solving Problems)

Perumusan strategi melibatkan serangkaian proses kontrol yang kritis untuk mengarahkan seorang siswa untuk secara efektif mengenali, merumuskan dan memecahkan masalah. Keterampilan ini ditandai dengan kemampuan memilih atau merancang rencana atau strategi untuk menggunakan matematika dalam memecahkan masalah yang timbul dari tugas atau konteks (OECD, 2013a; OECD, 2013b).

f. Menggunakan Bahasa dan Operasi Simbolik, Formal, dan Teknis, serta Operasi (Using Symbolic, Formal, and Technical Language, and Operations)

Kemampuan ini berkaitan dengan kompetensi mengaktifkan pengetahuan konten matematika, seperti definisi-definisi matematis, hasil (fakta), aturan-aturan, algoritma dan prosedur, menggunakan ekspresi simbolik (seperti kecepatan dan rata-rata), memahami 
dan memanipulasi formula, hubungan fungsional ataupun ekspresi aljabar yang lain. Turner (2012) menyatakan level kemampuan ini akan semakin bertambah seiring dengan bertambahnya kompleksitas konten matematika dan pengetahuan proseduran yang dibutuhkan.

g. Menggunakan Alat-Alat Matematika (Using Mathematical Tools)

Kemampuan ke-tujuh dalam literasi matematika adalah kemampuan menggunakan alat-alat matematika. Alat-alat matematika yang dimaksud di sini berhubungan dengan kemampuan menggunakan beragam alat fisik seperti kalkulator, alat berbasis komputer.

Dalam menjawab soal-soal PISA, seseorang perlu mengaktivasi berbagai kemampuan dasar matematika yang mencerminkan kerangka PISA.Semakin sulit pula soal PISA, semakin bertambah pula kemampuan yang dibutuhkan untuk mengaktifkan kemampuan dasar tersebut. Untuk tujuan memperjelas perbedaan dari tiap-tiap kemampuan dasar matematika,Turner (2012) telah mendefinisikan secara operasional enam macam kompetensi yang kemudian dikategorikan ke dalam empat level (level 0, 1, 2, 3). Namun demikian, perlu diketahui bahwa keenam kemampuan tersebut bisa saja saling tumpang tindih sampai batas tertentu.

\section{Level Soal dalam PISA}

Level kemampuan dalam soal PISA terdiri dari 6 level.Dalam hal ini, level menunjukkan tingkat kerumitan soal. Semakin tinggi level kemampuan dalam PISA, maka soalnya akan semakin rumit. Level kemampuan tertinggi adalah level 6 dan level terendah adalah level 1. Berikut adalah deskripsi masing-masing level soal tersebut (OECD, 2013a; OECD, 2013b).

\section{a. Level 6}

Pada level ini siswa dapat melakukan konseptualisasi dan generalisasi dengan menggunakan informasi berdasarkan modeling dan penelaahan dalam suatu situasi yang kompleks. Siswa dapat menghubungkan sumber informasi berbeda dengan fleksibel dan menerjemahkannya.

b. Level 5

Pada level 5, siswa dapat bekerja dengan model untuk situasi yang kompleks, mengetahui kendala yang dihadapi, dan melakukan dugaan-dugaan.Mereka dapat memilih, membandingkan, dan mengevaluasi strategi untuk memecahkan masalah yang rumit yang berhubungan dengan model. 
c. Level 4

Pada level ini, siswa dapat bekerja secara efektif dengan model dalam situasi yang konkret tetapi kompleks. Mereka dapat memilih dan mengintegrasikan representasi yang berbeda, dan menghubungkannya dengan situasi nyata.

d. Level 3

Pada level 3, siswa dapat melaksanakan prosedur dengan baik, termasuk prosedur yang memerlukan keputusan secara berurutan.Mereka dapat memilih dan menerapkan strategi memecahkan masalah yang sederhana.

e. Level 2

Siswa dalam level ini dapat menginterpretasikan dan mengenali situasi dalam konteks yang memerlukan inferensi langsung. Siswa dapat memilah informasi yang relevan dari sumber tunggal dan menggunakan cara representasi tunggal.

f. Level 1

Siswa pada level ini dapat menjawab pertanyaan yang konteksnya umum dan dikenal serta semua informasi yang relevan tersedia dengan pertanyaan yang jelas. Siswa bisa mengidentifikasi informasi dan menyelesaikan prosedur rutin menurut instruksi yang eksplisit.Siswa dapat melakukan tindakan sesuai dengan stimulus yang diberikan.

\section{Tipe Soal PISA}

Bentuk soal dalam PISA secara umum ada tiga (OECD, 2013a; OECD, 2013b), yaitu:

a. Open constructed-response type

Bentuk soal ini merupakan jenis soal terbuka, artinya siswa diminta untuk memberi jawaban atau respon terhadap permasalahan dengan cara menulis langkah-langkah penyelesaian atau strategi yang digunakan dalam menyelesaikan permasalahan tersebut. Biasanya bentuk soal seperti ini memiliki kemungkinan jawaban benar yang beragam.

b. Closed constructed-response type

Soal bentuk ini menyediakan pengaturan yang lebih terstruktur dalam menyajikan solusi dari soal, dan memungkinkan siswa untuk memberi jawaban yang dapat dengan mudah dinilai sebagai jawaban benar atau salah. Sebab pada soal bentuk ini, siswa hanya diminta untuk menulis jawaban dalam bentuk numerik atau dalam bentuk lain yang sifatnya tertutup, misalnya mengisi titik-titik dengan jawaban akhirnya saja tanpa menulis cara bagaimana menyelesaikan permasalahan tersebut. 


\section{c. Selected-response (Multiple-choice type)}

Bentuk soal ini menuntut siswa untuk memilih salah satu jawaban yang dianggap paling benar dari beberapa alternatif jawaban, misalnya memilih salah satu jawaban dari opsi A, B, C, D, atau E.

\section{Soal Matematika Model PISA sebagai Materi Program Pengayaan \\ 1. Karakteristik Soal Pengayaan dan Soal PISA}

Tujuan utama dari program pengayaan adalah memberikan kesempatan dan pengalaman belajar pada level lebih tinggi kepada peserta didik yang telah mencapai ketuntasan belajar lebih awal. Program pengayaan didesain berbeda dengan pembelajaran biasa, di mana cakupan materinya lebih luas dan mendalam sehingga diharapkan mampu memberikan tantangan belajar yang lebih tinggi kepada siswa.

Salah satu bentuk program pengayaan adalah dengan permberian masalah level tinggi guna mengembangkan kemampuan berpikir tingkat tinggi (high order thinking) siswa (McAllister \& Plourde, 2008; Gustiningsi, 2016). Salah satu karakteristik soal pemecahan masalah yang direkomendasikan dalam program pengayaan adalah soal yang mengacu pada permasalahan dunia nyata (Rule, Schneider, Tallakson, \& Highnam, 2012; Wardani, 2014). Permasalahan dunia nyata yang dimaksud sejalan dengan karakteristik soal PISA, yakni mengacu pada konteks dunia nyata. Selain itu, Renzulli \& Reis (2008; Wardani, 2014) memaparkan lebih lanjut kesamaan karakteristik soal pengayaan dan soal model PISA.

Tabel 1. Karakteristik Soal Pengayaan dan Soal PISA

\begin{tabular}{|c|c|c|}
\hline No. & Karakteristik Soal Pengayaan & teristik Soal PISA \\
\hline 1 & $\begin{array}{l}\text { Mengembangkan kemampuan dalam } \\
\text { mengkomunikasian penjelasan dan } \\
\text { argumen dalam pemilihan strategi } \\
\text { penyelesaian masalah (Renzulli \& Reis, } \\
\text { 2008). }\end{array}$ & $\begin{array}{l}\text { Membangun } \\
\text { mengkomunikasikan pendapat dan } \\
\text { interpretasi dari masalah (Level } 4 \text { dan 6). } \\
\text { Mampu memilih dan mengevaluasi } \\
\text { strategi penyelesaian yang sesuai untuk } \\
\text { tiap masalah (Level 5) (Wardani, 2014). }\end{array}$ \\
\hline 2 & $\begin{array}{l}\text { Mengembangkan kemampuan } \\
\text { representasi dari masalah menuju ke } \\
\text { model matematika (Renzulli \& Reis, } \\
\text { 2008). }\end{array}$ & $\begin{array}{l}\text { Beerja secara efektif dengan model dalam } \\
\text { situasi yang kompleks (Level } 4,5 \text { dan 6) } \\
\text { (Wardani, 2014). }\end{array}$ \\
\hline 3 & $\begin{array}{l}\text { Melakukan penarikan kesimpulan } \\
\text { berdasarkan hasil investigasi }\end{array}$ & $\begin{array}{l}\text { Melakukan konseptualisasi dan } \\
\text { generalisasi menggunakan informasi } \\
\text { berdasarkan investigasi terhadap masalah } \\
\text { (Level 6) (Wardani, 2014). }\end{array}$ \\
\hline
\end{tabular}




\begin{tabular}{ll}
\hline Memberikan kesempatan untuk & Merefleksi dan mempertimbangkam \\
merefleksi tindakan yang dilakukan & temuan dalam penyelesaian masalah dan \\
dalam penyelesaian masalah dan & mengkomunikasikan interpretasi dan \\
menginterpretasikan dengan bai hasil pendapatnya (Level 5 dan 6) (Wardani, & \\
dari refleksi terebut (Renzulli \& Reis, & 2014). \\
2008) &
\end{tabular}

Berdasarkan uraian di atas, terlihat jelas bahwa ada keterkaitan antara soal program pengayaan dengan soal PISA dan model PISA. Dengan demikian, soal matematika model PISA dapat menjadi alternatif jenis soal yang dapat digunakan oleh guru dalam program pengayaan guna mengoptimalkan kemampuan matematis siswa.

\section{Contoh Soal PISA (Matematika)}

Sebagai gambaran, berikut adalah contoh soal yang telah diujikan dalam survey PISA tahun 2012.

Tabel 2. Contoh Soal PISA 2012 (OECD, 2013b)

\begin{tabular}{l} 
Soal \\
\hline PIZZA \\
A pizzeria serves two round pizzas of the same thickness in \\
different sizes. The smaller one has a diameter of $30 \mathrm{~cm}$ and costs \\
30 zeds. The larger one has a diameter of $40 \mathrm{~cm}$ and costs 40 zeds. \\
Which pizza is better value for money? Show your reasoning. \\
\hline PIZZA \\
Seorang tukang pizza menyajikan dua buah pizza yang berbentuk \\
bundar dengan ketebalan yang sama namun dengan ukuran yan \\
berbeda. Pizza yang lebih kecil berdiameter $30 \mathrm{~cm}$ dengan harga \\
30 zeds, sedangkan pizza besar berdiameter $40 \mathrm{~cm}$ dengan harga \\
40 zeds. \\
Pizza mana yang sebaiknya dipilih? Jelaskan alasanmu.
\end{tabular}

\section{Profil Soal}

a. Kategori

Tabel 3. Profil Soal

\begin{tabular}{ll}
\hline Deskripsi & $\begin{array}{l}\text { Menggunakan konsep perbandingan (luas permukaan } \\
\text { dan harga) untuk menentukan pizza yang lebih murah }\end{array}$ \\
Konten & $\begin{array}{l}\text { Change and relationships (Perubahan dan hubungan) } \\
\text { Konteks }\end{array}$ \\
Level & 3 \\
Tipe soal & Open constructed-response \\
\hline
\end{tabular}


b. Kemampuan Dasar Matematika (KDM)

Tabel 4. KDM Soal

\begin{tabular}{|c|c|c|}
\hline KDM & Level & Deskripsi \\
\hline Komunikasi & 1 & $\begin{array}{l}\text { Melibatkan kemampuan membaca yang } \\
\text { sederhana untuk memahami istilah-istilah } \\
\text { secara matematis, seperti bundar, } \\
\text { ketebalan yang sama, dan ukuran yang } \\
\text { berbeda. }\end{array}$ \\
\hline Representasi & 1 & $\begin{array}{l}\text { Merumuskan representasi yang relevan } \\
\text { dengan masalah, termasuk representasi } \\
\text { simbol pada rumus untuk menghitung } \\
\text { luas permukaan dua pizza dan } \\
\text { representasi perbandingkan keduanya. }\end{array}$ \\
\hline Matematisasi & 1 & $\begin{array}{l}\text { Merumuskan model matematika yang } \\
\text { sesuai dengan masalah, yang selanjutnya } \\
\text { dapat digunakan untuk menentukan pizza } \\
\text { mana yang lebih murah. }\end{array}$ \\
\hline $\begin{array}{l}\text { Strategi } \\
\text { Pemecahan } \\
\text { Masalah }\end{array}$ & 2 & $\begin{array}{l}\text { Menentukan pendekatan yang sesuai } \\
\text { serta merumuskan strategi pemodelan } \\
\text { yang dibutuhkan untuk menentukan pizza } \\
\text { mana yang lebih baik dipilih. }\end{array}$ \\
\hline $\begin{array}{l}\text { Penalaran dan } \\
\text { Argumentasi }\end{array}$ & 2 & $\begin{array}{l}\text { Menentukan bahwa ketebalan pizza dapat } \\
\text { diabaikan dan menghubungkan antara } \\
\text { luas permukaan dan harga masing- } \\
\text { masing pizza. }\end{array}$ \\
\hline $\begin{array}{l}\text { Penggunaan } \\
\text { Bahasa/ Operasi } \\
\text { Simbolik }\end{array}$ & 1 & $\begin{array}{l}\text { Menggunakan perhitungan sederhana } \\
\text { dalam menghitung luas permukaan dua } \\
\text { pizza serta membandingkan harga dan } \\
\text { luas keduanya. }\end{array}$ \\
\hline
\end{tabular}

Level soal pada setiap kemampuan dasar matematis dapat disertakan dalam profil soal seperti pada tabel di atas dengan menggunakan kriteria penentuan level yang telah kemukakan oleh Turner (2012).

\section{Contoh Soal Matematika Model PISA}

Dalam implementasi program pengayaan berupa pemberian soal-soal pemecahan masalah kontekstual dalam pembelajaran, guru dapat mengadopsi atau memodifikasi soalsoal PISA yang telah diujikan. Bahkan dalam level yang lebih inovatif, guru bisa saja 
mengembangkan soal-soal matematika model PISA yang disesuaikan dengan kebutuhan materi ajar. Soal-soal matematika yang dikembangkan berdasarkan karakteristik soal yang diujikan dalam suvey PISA selanjutnya disebut sebagai soal matematika model PISA. Sebagai contoh, berikut disajika contoh soal matematika model PISA untuk siswa SMP Kelas VII pada materi perbandingan.

\section{UNIT 1: HARGA BBM}

\section{Soal 1}

Dino melihat berita pada Kompas TV yang menyiarkan rencana pemerintah untuk menaikkan harga Bahan Bakar Minyak (BBM) jenis premium dan solar dengan besar kenaikan sebagai berikut.

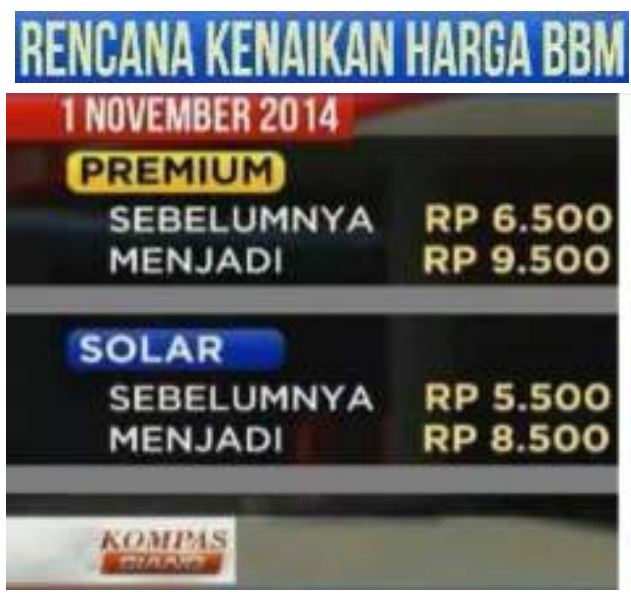

Sumber:

https://sijidewe.files.wordpress.com/2 014

Menurut Dino, persentase kenaikan harga premium dan solar adalah sama. Setujukah kamu dengan pendapat Dino? Jelaskan strategi penyelesaianmu.

Sumber: Dewantara, A.H, dkk, 2015

Berdasarkan unit soal "Harga BBM" di atas, terlihat bahwa materi perbandingan dapat dituangkan ke dalam bentuk soal-soal pemecahan masalah non rutin yang sifatnya kontekstual dan dekat dengan dunia nyata siswa. Soal-soal semacam ini diharapkan mampu memberi pengalaman dan tantangan belajar baru bagi siswa dalam program pengayaan. Melalui soal matematika model PISA, diharapkan mampu mengoptimalkan kemampuan literasi matematis siswa melalui aktivasi kemampuan dasar matematis di antaranya kemampuan komunikasi, representasi, matematisasi, pemecahan masalah, penalaran dan argumentasi, serta penggunaan bahaasa/operasi simbolik, sehingga tujuan dari program pengayaan dapat tercapai secara lebih maksimal. 


\section{PENUTUP}

Program pengayaan dapat diartikan sebagai sebuah aktivitas belajar yang berisi tantangan belajar pada level yang lebih tinggi dibanding pembelajaran rutin, yang diperuntukkan bagi peserta didik yang telah melampaui persyaratan minimal yang ditentukan oleh kurikulum, guna mengoptimalkan aktivasi kemampuan kognitif, afektif, dan psikomotorik siswa. Salah satu tantangan belajar yang dapat diterapkan dalam program pengayaan ini yakni pemberian soal-soal pemecahan untuk melatih kemampuan berpikir tingkat tinggi (high order thinking) siswa..

Soal-soal yang diujikan dalam survey internasional PISA atau soal-soal yang dikembangkan serupa dengan soal PISA (soal model PISA) memiliki karakteristik yang sangat sesuai dengan karateristik soal pengayaan. Dengan kata lain, soal matematika model PISA dianggap sebagai bentuk soal yang sangat sesuai diberikan kepada siswa-siswa yang telah mencapai ketuntasan belajar lebih awal sebagai materi program pengayaan. Pemberian soal-soal non rutin dalam program pengayaan diharapakan mampu mengoptimalkan kemampuan literasi matematis siswa melalui aktivasi kemampuan dasar matematis, yang pada akhirnya dapat membantu keberhasilan program pengayaan dalam mengembangkan kecakapan siswa secara lebih optimal.

\section{DAFTAR PUSTAKA}

OECD. 2010. PISA 200 Results: Executive Summary. Paris: OECD Publishing.

OECD. 2013a. PISA 2012. Assessment and Analytical Framework: Mathematics, Reading, Science, Problem Solving and Financial Literacy. Paris: OECD Publishing.

OECD. 2013b. PISA 2015 Draft Mathematics Framework. Paris: OECD Publishing.

Johar, R. 2012. Domain PISA untuk Literasi Matematika. Jurnal Peluang, 1(1), 30-41.

Gustiningsi, T. 2016. Pengembangan Soal Pengayaan Model PISA Level 4 Kelas VII SMP, Jurnal Pendidikan Matematika (JPM) RAFA, 2(2), 198-213.

McAllister, B.A., \& Plourde, L.A. 2008. Enrichment Curriculum: Essential for Mathematically Gifted Students, Education, 129(1), 40-49.

Sanova, Y, Zulkardi, \& Hartono, Y. 2017. Pengembangan Soal Pengayaan Matematika Online untuk Siswa Kelas X, Jurnal Elemen, 3(1), 58-67.

Stacey, K. 2011. The PISA View of Mathematical Literacy in Indonesia, Journal on Mathematics Education (IndoMS-JME), 2(2),95-126. 
Renzulli, J., \& Reis, S. 2007. A Technology Based Program that Matches Enrichment Resources with Students Strengths, International Journal of Emerging Technologies in Learning (iJET), 2(3).

Rule, A.C., Schneider, J.S., Tallakson, D.A., \& Highnam, D. 2012. Creativity and Thinking Skills Integrated into a Science Enrichment Unit on Flooding. Creative Education, 3(8), 1371-1379.

Dewantara, A.H., Zulkardi, \& Darmawijoyo. 2015. Assessing Seventh Graders' Mathematical Literacy in Solving PISA-like tasks, Journal on Mathematics Education (IndoMS-JME), 6(2), 117-127.

Wardani, A.Kusuma. 2014. Pengembangan Soal Matematika Model PISA untuk Pengayaan Kelas VII SMP. Tesis. Palembang: FKIP Universitas Sriwijaya. 